\title{
Sanggah Kemulan Nganten dan Pelangkiran: obyek penentu keberlangsungan rumah tinggal tradisional Desa Pedawa, Bali
}

\author{
Tri Anggraini Prajnawrdhi' ${ }^{1}$ dan Ni Luh Putu Pebriyanti ${ }^{2}$
}

\author{
${ }^{1}$ PS Arsitektur/Fakultas Teknik, Universitas Udayana \\ 2 PS Arsitektur/Fakultas Teknik, Universitas Udayana \\ anggieprajnawrdhi@unud.ac.id
}

\begin{abstract}
ABSTRAK
Bentuk dan karakter arsitektur tradisional di Bali berkaitan erat dengan budaya, adat istiadat dan system religi masyarakat Bali. Bangunan rumah tinggal tradisional Bali yang merupakan bagian dari Arsitektur Nusantara yang diwariskan secara turun temurun yang masih ada hingga saat ini dan menjadi bukti sejarah nenek moyang kita. Konsep Tri Hita Kharana sebagai wujud kedekatan masyarakat Bali dengan alam dan Sang pencipta melandasi konsep permukiman desa-desa Bali Aga, dan merupakan konsep yang dipegang teguh di dalam melestarikan arsitektur tradisional Bali. Kepercayaan terhadap leluhur, tradisi masyarakat sebagai pembuat gula aren, alam dan lingkungan sekitar; dan pandangan hidup masyarakat Desa Pedawa telah membentuk sebuah karakter rumah tinggal tradisional yang unik. Penelitian ini bertujuan untuk menemukan faktor terpenting dari rumah tinggal tradisonal Desa Bali Aga di Desa Pedawa yang membuat rumah tradisional ini masih lestari hingga saat ini. Melalui metode studi kasus yang meliputi observasi lapangan, wawancara dan penelusuran sejarah serta analisa deskriptif menunjukkan bahwa terdapat dua faktor terpenting terhadap keberlangsungan rumah tradisional Desa Pedawa yaitu Sanggah Kemulan Nganten dan Pelangkiran.
\end{abstract}

Kata kunci: rumah tinggal tradisional, Pelangkiran, Sanggah Kemulan Nganten

\section{ABSTRACT}

Balinese traditional architecture's form and character are associated to its culture, custom and religious system of the Balinese. Traditional Balinese house as part of the Nusantara Architecture are inherited from our ancestors and have become the evident of our history. Tri Hita Kharana is the concept which reflect a close relationship between the Balinese with the nature and the God, which become the foundation of traditional setllement in Bali Aga vilages, thus it also become the main concept in preserving Balinese traditional architecture. The unique character of traditional house in desa Pedawa formed by people's belief of their ancestor; their tradition as palm sugar maker; their nature and surrounding areas; and their way of life. This research aimed to discover the important factor from this traditional house which preserve this house to this moment. Case study method includes field observation, interview and historical study with the use of descriptive analysis has presented that Sanggah Kemulan Nganten and Pelangkiran are the two most important factors in preserving the traditional house in Desa Pedawa.

Keywords: traditional house, Pelangkiran, Sanggah Kemulan Nganten

\section{Pendahuluan}

Pertambahan penduduk yang menyebabkan perubahan demografi merupakan masalah yang sangat umum terjadi di negara-negara berkembang. Bali sebagai salah satu 
provinsi di Indonesia dan menjadi icon pariwisata dunia menghadapi permasalahan yang kompleks akibat pertumbuhan penduduk yang disebabkan dari arus migrasi. Ledakan jumlah penduduk, mengakibatkan harga lahan meningkat sehingga perubahan fungsi lahan dan bangunan tidak dapat dihindari. Arsitektur rumah tradisional di Bali khususnya pada desa Bali Aga tak pelak ikut mengalami transformasi pada bentuk maupun fungsi bangunan.

Rumah tinggal tradisional merupakan perwujudan dari symbol budaya setempat. Perwujudan rumah tinggal tradisional merupakan pengaruh dari kondisi budaya lokal. Broadbent (1973) menyatakan bahwa ekspresi karakteristik dari sebuah budaya setempat yang meliputi norma, nilai-nilai, pola tingkah laku, artefak serta aktifitas sebuah karya arsitektur diwujudkan dalam sebuah rumah tinggal tradisional. Senada dengan Broadbent, Schulz (1973) menyatakan bahwa ekspresi dari sistem sosial budaya masyarakat dan nilai-nilai yang telah disepakati bersama dalam sebuah lingkungan masyarakat diwujudkan dalam sebuah karya arsitektur. Dalam hal ini kaidah, nilai dan norma budaya masyarakat setempat merupakan landasan penting dalam sebuah karya arsitektur. Fungsi rumah tinggal tradisional yang ada di Bali memampung aktivitas fisik serta psikologis diantaranya: tidur, makan, istirahat dan juga untuk menampung kegiatan yang bertujuan untuk kepentingan psikologis, seperti melaksanakan upacara keagamaan dan adat (Sulistyawati, 1985). Rumah tinggal tradisional juga merupakan sebuah wadah untuk menampung kebutuhan manusia baik dari kebutuhan dasar hingga kebutuhan yang lebih tinggi. Seiring dengan berjalannya waktu, kebutuhan manusia akan berubah maupun bertambah hingga perubahan terhadap sebuah rumah tinggal tidak akan dapat dihindari. Disini jelas terlihat bahwasanya rumah tradisional di Bali memiliki fungsi yang mampu mewadahi segala macam kegiatan baik fisik maupun psikologis dari penghuninya.

Penelitian-penelitian terhadap rumah tinggal tradisional di Bali telah banyak dilakukan sebelumnya. Dari penelitian yang sudah dilakukan terhadap rumah tradisional Bali yaitu terdapat empat buah atribut pada perumahan tradisonal Bali diantaranya: (1) Atribut Sosiologi menyangkut sistem kekerabatan masyarakat Bali; (2) Atribut Simbolik berkaitan dengan orientasi perumahan, orientasi sumbu utama desa, orientasi rumah dan halamannya; (3) Atribut Morpologi menyangkut komponen yang ada dalam suatu perumahan inti (core) dan daerah periphery di luar perumahan; dan (4) Atribut Fungsional menyangkut fungsi perumahan tradisional Bali pada dasarnya berfungsi keagamaan dan fungsi sosial yang dicirikan dengan adanya 3 pura desa (Parimin, 1986).

Terdapat total 62 desa Bali Aga yang tersebar di seluruh Bali yang belum semua diteliti secara mendalam (Muller, 1980). Saat ini telah dilakukan identifikasi dan inventarisasi terhadap Desa-Desa Tradisional di Bali oleh Pemerintah Propinsi Daerah Tingkat I Bali, Dinas Pekerjaan Umum Propinsi Bali, Proyek Perencanaan Konservasi Lingkungan Desa tahun 1988/1989. Beberapa desa Bali Aga yang sudah pernah diteliti secara arsitektural yaitu diantara: desa Buahan, desa Pinggan dan desa Sukawana telah dilakukan oleh Yudantini pada tahun 2013, desa Trunyan oleh Dwijendra pada tahun 2015, desa Penglipuran oleh Widarji pada tahun 2014, desa Tenganan oleh Hadi Kusuma pada tahun 2014; Kumurur pada tahun 2009; Purwantiasning pada tahun 2007; dan beberapa desa Bali Aga lainnya yang termasuk sebagai kawasan wisata. Namun Desa Pedawa yang memiliki keunikan tersendiri belum pernah diteliti secara arsitektural, hanya sebatas pada bidang pertanian khususnya pada tanaman kopi (www.pps.unud.ac.id); di bidang pengelolaan dana desa Adat dan Desa Dinas oleh Tera Padmani, dkk pada tahun 2015; penelitian di bidang kesehatan oleh Budiarta dan Suka 
Aryana pada tahun 2012; penelitian terhadap pengaruh model pembelajaran anak-anak SD di desa Pedawa oleh Komang Arini, dkk pada tahun 2013; dan beberapa survey lapangan yang telah dilakukan pada desa ini tetapi tidak terpublikasikan. Dari semua penelitian yang pernah dilakukan di Desa Pedawa, tidak satupun yang berkaitan dengan arsitektur rumah tradisional yang ada pada desa ini. Oleh sebab itu penelitian ini memilih untuk mengkaji arsitektur rumah tradisional di desa Pedawa yang belum pernah dilakukan sebelumnya oleh peneliti terdahulu.

Rumah tinggal tradisional di Desa Pedawa ini memiliki keunikan tersendiri baik dari bentuk, bahan bangunan serta pola dan fungsi ruang pada rumah ini. Bentuk maupun pola ruang dalam rumah tradisional Desa Pedawa memiliki keterkaitan yang erat dengan pandangan dan pola hidup masyarakat setempat. Pada setiap rumah tradisional selalu memiliki sebuah tempat suci yang letaknya di luar rumah dan berada di hulu rumah yang terbuat dari bambu disebut dengan Sanggah Kemulan Nganten yang berarti tempat suci untuk memuja leluhur dan Batara batari bagi keluarga yang sudah menikah. Setiap masyarakat desa Pedawa yang sudah menikah dan membentuk sebuah keluarga wajib untuk memiliki Sanggah Kemulan Nganten. Pemujaan terhadap leluhur juga khusus dibuatkan didalam rumah yang posisinya berada di bagian langit-langit rumah tradisional tepat diatas tempat tidur orang tua, dan tempat pemujaan ini disebut dengan Pelangkiran. Disini dapat dilihat bahwa rumah tinggal tradisional memiliki keunikan yang sangat mengutamakan kegiatan persembahyangan terhadap leluhur dan DewaDewi yang berstana pada Pura-Pura suci Dang Kahyangan yang ada di Bali.

Seiring dengan pesatnya pertambahan penduduk di Bali khususnya bukan dari pertambahan penduduk alami melainkan dari arus migrasi dari luar pulau Bali, perubahan pada pola dan bentuk rumah tinggal tradsional Bali tidak dapat dihindari. Tulisan ini bertujuan untuk meneliti bagaimana perubahan yang terjadi pada rumah tinggal tradsional di Desa Pedawa; permasalahan apa saja yang timbul akibat perubahan tersebut; faktor-faktor penyebab perubahan; serta mampu menentukan faktor terpenting bagi keberlangsungan rumah tinggal tradisional Desa Pedawa hingga masih bisa bertahan sampai saat ini.

\section{Bahan dan Metode}

Penelitian ini menggunakan metode studi kasus untuk meneliti rumah tinggal yang ada di desa Pedawa yang termasuk salah satu desa Bali Aga di Bali. Stake (1978) menyatakan bahwa metode ini mampu membantu peneliti untuk mendapatkan suatu metode penelitian yang menyeluruh terhadap obyek yang diteliti, sehingga peneliti dapat melakukan eskplorasi terhadap obyek studi dengan lebih mendalam. Data-data yang di dapat dari berbagai macam metode pengumpulan data dan juga kombinasi dari metode pengumpulan data baik dari segi kualitatif maupun kuantitatif seperti data yang bersumber dari interview, kuisioner, observasi, dokumentasi, survey lapangan, data-data sejarah dan arsip-arsip yang telah ada data diolah melalui metode studi kasus (Chetty 1996; Eisenhardt 1989).

Melalui metode ini, peneliti juga mampu mengkaji keterkaitan antara obyek yang diteliti terhadap aspek-apek seperti: perubahan-perubahan perilaku pada individu, perubahan perilaku yang terjadi di masyarakat terjadi di masyarakat, demikian juga dengan kejadian penting yang terjadi pada masyarakat yang diteliti. Sehingga, metode ini sangat tepat dipergunakan untuk penelitian yang terkait dengan ilmu-ilmu social (Yin 2009). Disamping melihat perubahan perilaku yang terjadi pada individu dan 
masyarakat, metode ini juga membantu peneliti untuk dapat melakukan sebuah analisa deskriptif terhadap hubungan antara obyek yang diteliti terhadap factor-faktor lainnya seperti sejarah, dan perilaku masyarakat setempat. Data primer yang berasal dari observasi langsung maupun wawancara, dapat diolah bersamaan dengan data sekunder seperti laporan dokumentasi dan sebagainya dapat diolah untuk mendapatkan suatu hasil akhir yang optimal melalui sebuah metode studi kasus (McCutcheon \& Meredith 1993). Penelitian ini menggunakan data primer dan sekunder yang didapatkan pada saat observasi lapangan dan data dari instansi terkait. Selanjutnya, data-data yang telah terkumpul akan dianalisa dengan menggunakan analisa deskriptif kualitatif.

\section{Hasil dan Diskusi}

\subsection{Sekilas tentang Desa Pedawa}

Desa Pedawa berada pada posisi ketinggian berkisar diantara 450-800 meter dari atas permukaan laut. Desa ini terletak pada jarak $12 \mathrm{~km}$ dari Kota Kecamatan Banjar dan $30 \mathrm{~km}$ dari Kota Kabupaten Buleleng yaitu Singaraja. Desa ini adalah salah satu dari beberapa desa tua yang berada di Kecamatan Banjar, Kabupaten Buleleng. Desa ini sudah ada sejak jaman Megalithikum dengan bukti sejarah dua buah sarkopagus, yang ditemukan pada wilayah Banjar Dinas Ingsakan dan wilayah Jinjit yang masih ada hingga saat ini. Sebelum bernama Desa Pedawa, desa ini mengalami dua kali pergantian nama yaitu (1) Gunung Tambleg dan (2) Gunung Sari. Gunung Tambleg berarti orang-orang yang lugu. Kemudian diganti menjadi Gunung Sari yang berarti daerah yang subur. Kemudian pada abad 15 akhirnya nama Pedawa dipilih untuk desa ini yang berarti Panjak Dewa (anak buah dewa) seperti yang tersurat pada babad Pasek Kayu Selem. Kata Pedawa juga berasal dara kata Pada Wang yang berarti orang yang sama/ kesamen. Dengan demikian di desa ini tidak mengenal kasta dan semua orang setara dan memiliki tingkatan yang sama. Peta desa Pedawa dapat dilihat pada gambar 1 dibawah ini.

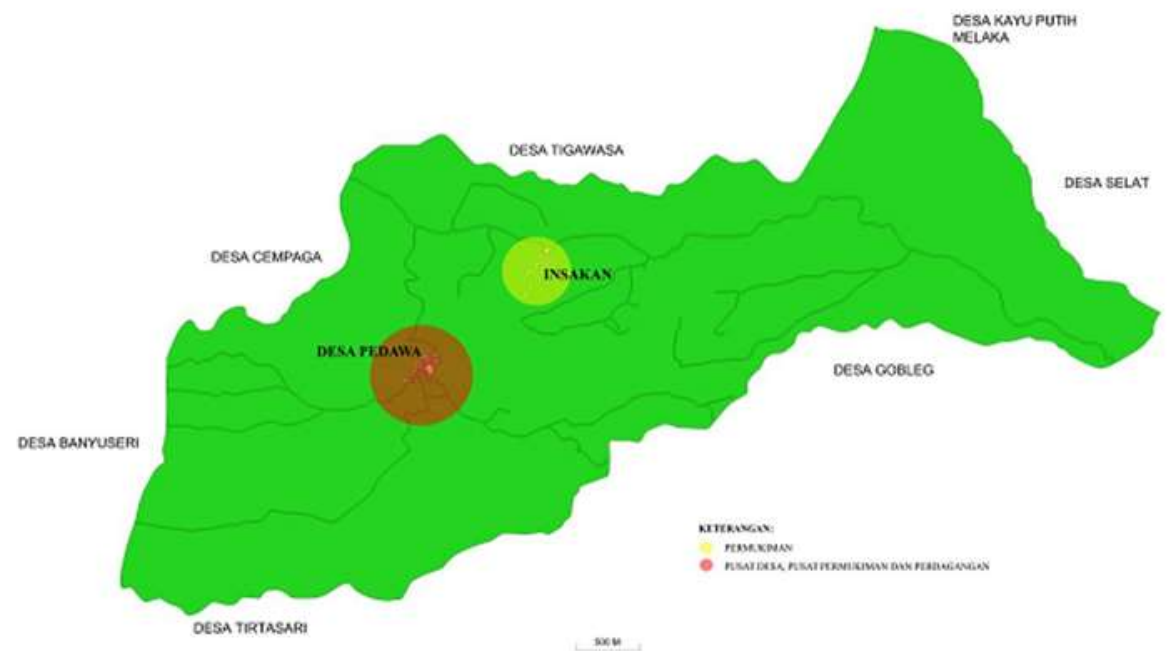

Gambar 1. Peta Desa Pedawa

(Sumber: hasil observasi penulis, 2016) 
Observasi lapangan dilakukan untuk mengkaji segala perubahan yang terjadi pada rumah tinggal tradisional di Desa Pedawa. Sebaran dari beberapa rumah tinggal tradisional yang dikaji terlihat pada gambar 2. Lokasi dari obyek kajian tersebar di pusat Desa Pedawa dan Dusun Ingsakan, karena hanya pada dua daerah ini saja masih terdapat rumah tingal tradisional yang masih sesuai dengan kategori rumah tinggal tradisional Desa Pedawa.

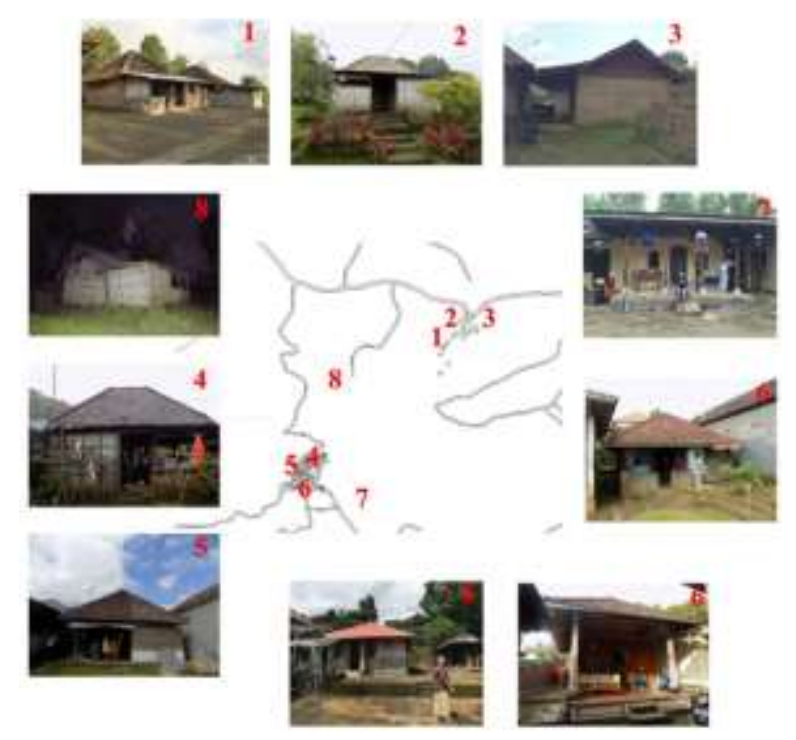

Gambar 2. Rumah tinggal tradisional Desa Pedawa (Sumber: hasil observasi penulis, 2016)

Semua angka harus diiringi dengan nomor dalam teks (misalnya Gambar. 1) dan diikuti keterangan. Keterangan harus cukup lengkap untuk memungkinkan pemahaman ilustrasi tanpa mengacu ke teks. Huruf dari judul harus sama besar dengan jenis huruf yang digunakan untuk teks artikel (Cambria 12). Selain itu, sumber gambar sendiri harus ditempatkan langsung di bawah gambar (penulis, tanggal) dengan font Cambria 9. Gunakan garis tunggal kosong sebelum dan sesudah gambar.

\subsubsection{Denah Rumah Tradisional Desa Pedawa}

Rumah tradisional Desa Pedawa merupakan masa bangunan tunggal yang memiliki berbagai fungsi ruang di dalam rumah tersebut (lihat Gambar 3 dan gambar 4). Terdapat dua buah tipe rumah tradisional yaitu (1) yang memiliki Saka/ tiang 18 disebut dengan Bandung Rangki dan (2) yang memiliki Saka / tiang 16 disebut dengan Sri Dandan. Semua fungsi ruang yang ada tidak memiliki batas tembok tetapi menyatu antar ruang satu dengan lainnya dan meiliki ruang kosong tepat berada di tengah-tengah bangunan. Fungsi-fungsi yang diwadahi pada rumah ini adalah sebagai berikut: (1) Fungsi istirahat, untuk mewadahi kegiatan istirahat terdapat dua buah bale istirahat yaitu Pedeman Gede/ Bale Gede yang terbuat dari kayu untuk tempat tidur orang tua dan tempat meletakkan sesajen pada saat ada upacara keagamaan Manusa Yadnya. Kemudian, terdapat juga Pedeman Alit/ Bale Alit yang terbuat dari kayu sebagai tempat tidur anak-anak; (2) Fungsi memasak dan membuat gula aren. Untuk mewadahi fungsi ini, terdapat sebuah dapur yang disebut dengan Paon yang memiliki bentuk khusus karena Desa Pedawa merupakan daerah penghasil gula aren yang sangat terkenal di Kabupaten Bueleng bahkan Pulau Bali. Paon terbuat dari tanah polpolan dan memiliki tiga tungku dengan berbagi ukuran yaitu Paon Tuak (berukuran paling besar yang 
dipakai untuk memasak gula aren), Paon Jakan (berukuran sedang untuk memasak nasi dan lauk pauk) dan Irun (berukuran sedikit lebih kecil dari Paon Jakan untuk memasak air minum dan menghangatkan makanan). Terdapat juga area penyimpanan diatas Paon yang bernama Lancat dan Penapen serta rak dari kayu yang berada di sebelah Paon yang dikenal dengan Selalon yang berfungsi untuk menyimpan makanan dan alat-alat dapur; (3) Fungsi sosial, untuk mewadahi aktifitas ini terdapat ruang kosong yang berada di tengah diantara ruang lainnya yang berfungsi untuk bercengkrama beserta anggota keluarga. Rumah ini juga memiliki teras depan yang bernama Terempang yang berfungsi untuk melakukan aktifitas sosial; (4) Fungsi Keagamaan. Rumah tradisional ini memiliki sebuah tempat suci yang letaknya di luar rumah dan memiliki posisi di hulu Pedeman Gede, dan tidak tergantung pada posisi arah letak mata angin tertentu seperti pada rumah tradisional Bali yang umum. Tempat suci ini disebut Sanggah Kemulan Nganten, dan terbuat dari bambu yang memiliki dua tingkatan untuk memuja leluhur, Dewa Dewi yang berstana di Pura Suci Dang Kahyangan di Bali dan Sang Pencipta yaitu Ida Sang Hyang Widi Wasa. Tempat suci lainnya berada di dalam rumah yaitu Pelangkiran yang berada tepat di atas Pedeman Gede, Pelangkiran ini berfungsi sebagai tempat untuk memuja leluhur dan melakukan persembahyangan keagamaan; kemudian fungsi yang terakhir adalah (5) Fungsi Penyimpanan.
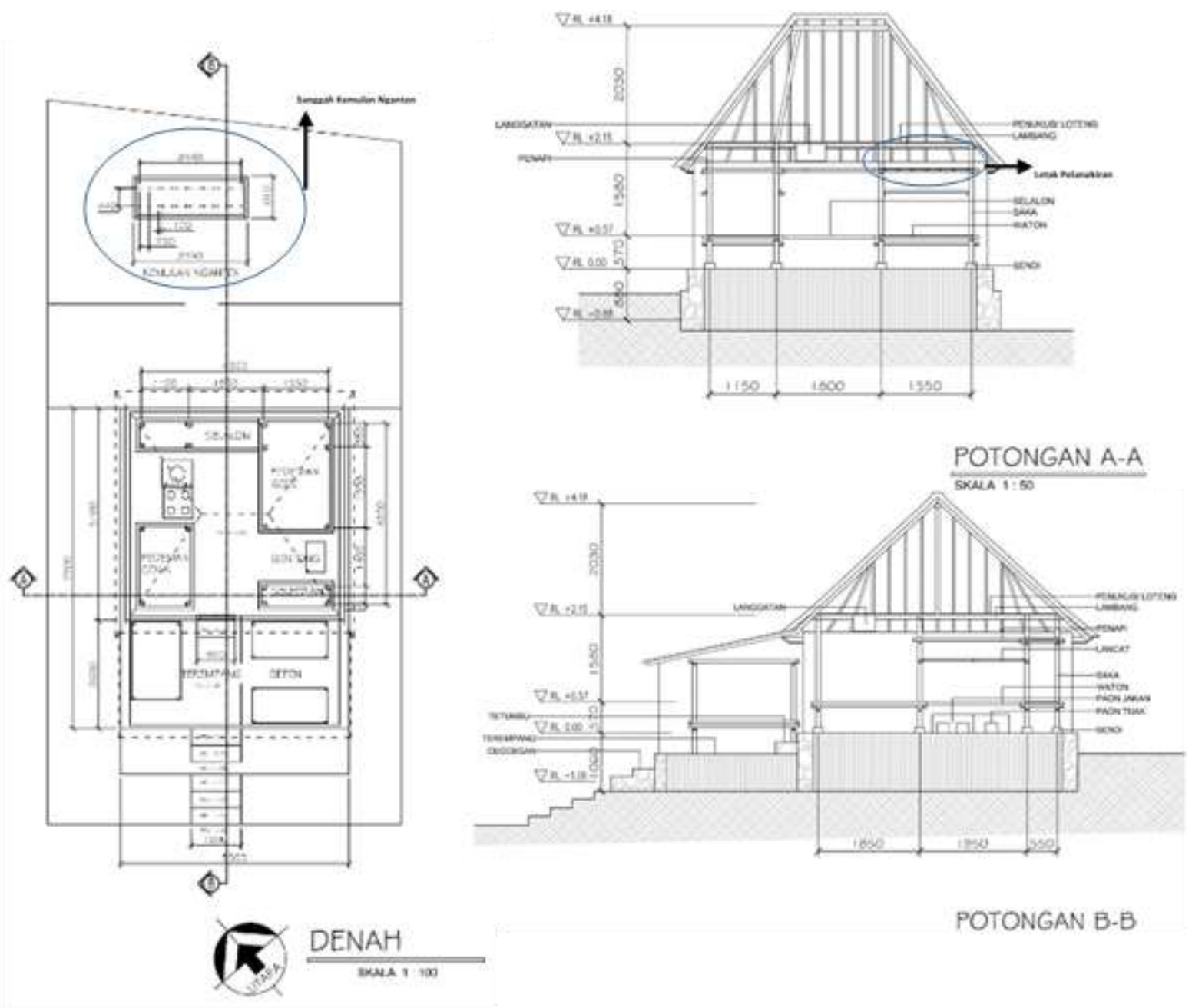

POTONGAN B-B

Gambar 3. Gambar Denah dan potongan Bandung Rangki

(Sumber: hasil observasi penulis, 2016) 
Ruang penyimpanan disebut dengan Sepen yaitu sebagai tempat menyimpan alat-alat upacara keagamaan dan alat rumah tangga, dan ruang ini memiliki batas dinding dengan ruang lainnya. Ruang ini terletak di depan ruman disebelah Terempang / teras. Bagi masyarakat yang memiliki mata pencaharian bertani, mereka memiliki lumbung sebagai tempat menyimpan padi mereka yang dikenal dengan nama Jineng. Jineng memiliki posisi yang berhadap hadapan dengan rumah tradisional dan memiliki natah/ halaman diantara kedua bangunan tersebut.
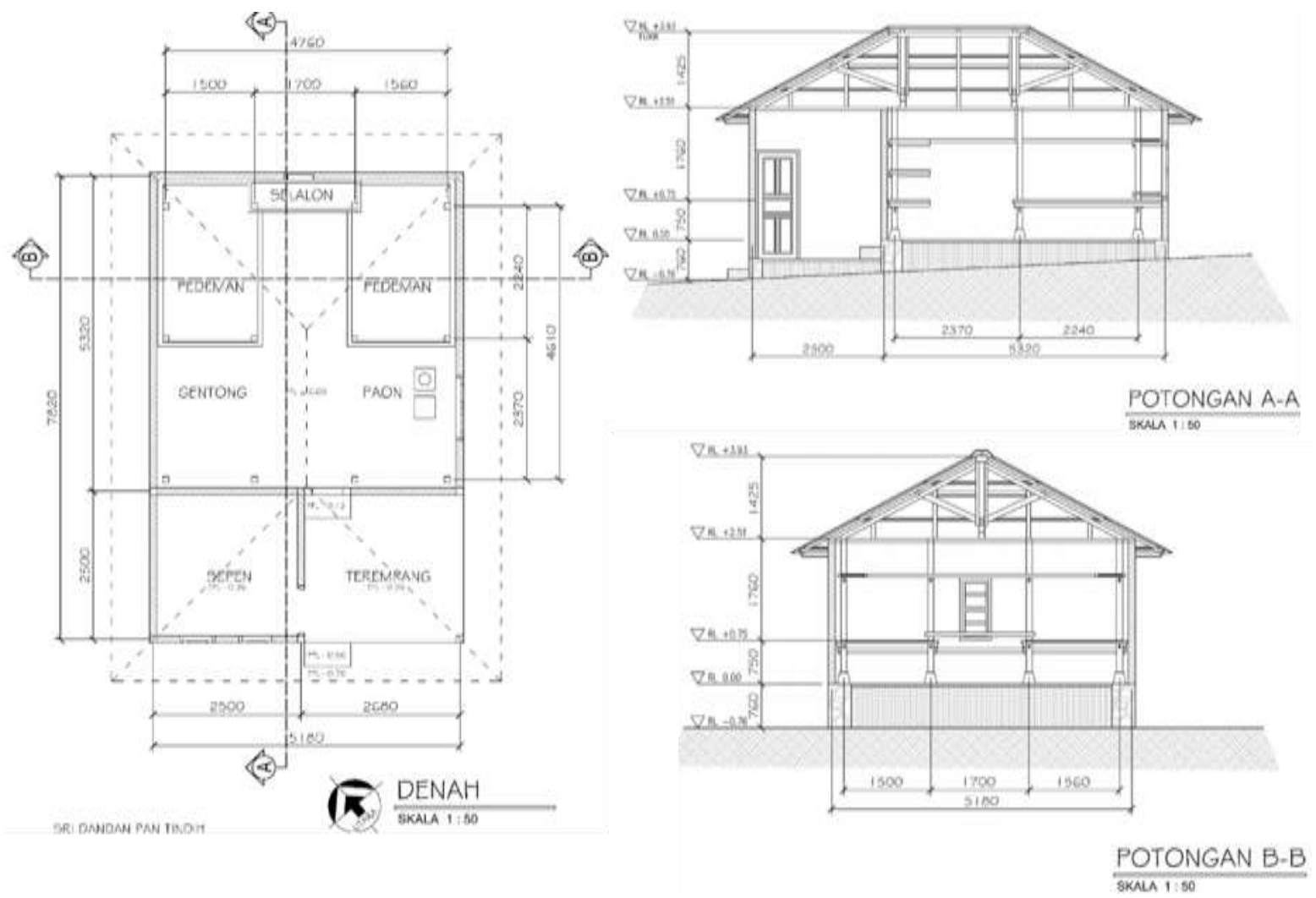

Gambar 4. Gambar Denah dan potongan Sri Dandan

(Sumber: hasil observasi penulis, 2016)

\subsubsection{Yang Berubah dan Yang Dipertahankan}

Perubahan terhadap wujud dan fungsi ruang pada rumah tradisonal ini sudah terjadi dan tidak dapat dihindari, dapat dijelaskan sebagai berikut:

1. Bangunan rumah tradisional memiliki struktur atap yang terbuat dari bambu dan memiliki bahan penutup atap dari sirap bambu dan alang-alang. Seiring dengan waktu, perubahan terhadap struktur dan bahan penutup atap tidak bisa dihindari. Karena sulitnya menemukan bahan bambu dan alang-alang yang berkualitas, bahan tersebut mudah hancur sehingga kemudian digantikan dengan bahan lain yaitu kayu sebagai bahan struktur atap dan genteng dan seng sebagai bahan penutup atap. Bahan-bahan ini dipilih karena lebih ekonomis dan tahan lama. Perubahan terhadap struktur dan bahan penutup atap ini akhirnya merubah bentuk atap mejadi lebih datar dan lebih pendek dari sebelumnya. 

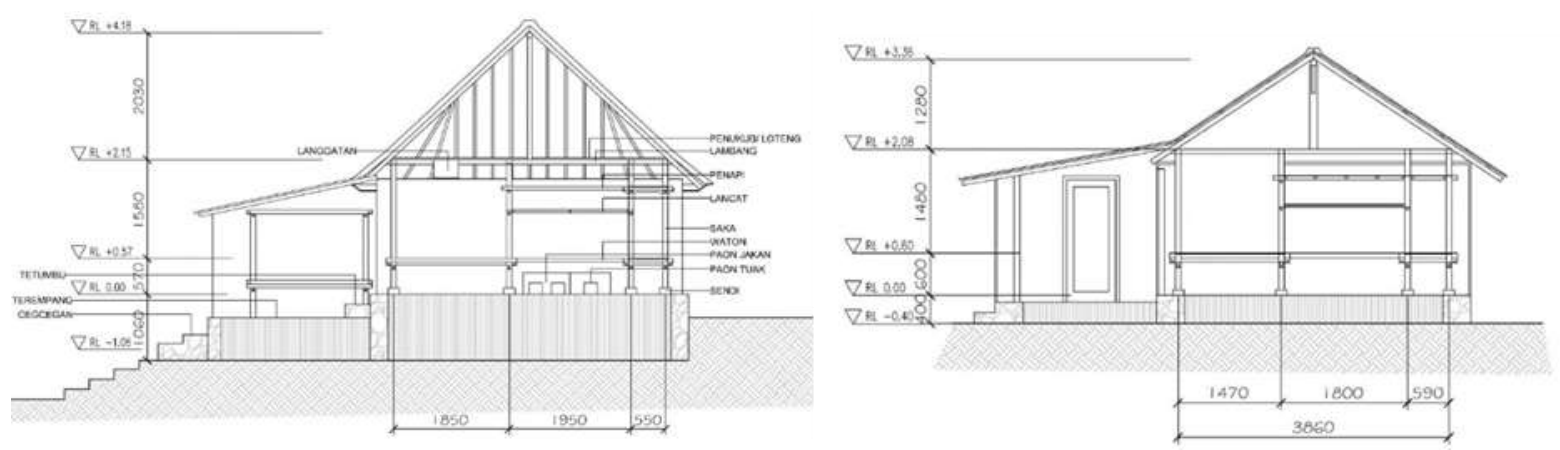

Gambar 5. Perbedaan tinggi atap asli (kiri) dengan atap baru (kanan)

(Sumber: hasil observasi penulis, 2016)

2. Struktur badan bangunan yang dulunya terbuat dari tiang kayu dan ditutup dengan anyaman bambu sebagai dinding dan hanya memiliki satu bukaan di dekat dapur sudah mengalami perubahan saat ini. Dinding sudah berganti menjadi kayu dan tembok bata, serta memiliki banyak bukaan. Hal ini menghilangkan identitas tampilan bangunan yang dulunya sangat sederhana dengan dinding anyaman bambu menjadi lebih modern dengan bahan kayu dan dinding bata yang dicat sesuai dengan selera penghuninya. Penambahan bukaan yaitu jendela membuat rumah menjadi lebih terang, namun secara tidak langsung membuat rumah menjadi lebih dingin karena lebih banyak udara yang masuk, sehingga pada akhirnya jendela jarang dibuka kecuali pada saat memasak.

3. Bagian bawah bangunan atau dalam konsep Tri Angga (pembagian bangunan menjadi: kepala, badan dan kaki) dikenal dengan kaki bangunan yaitu struktur lantai dan bataran. Bataran bangunan yang dulunya terbuat dari tanah polpolan sudah mengalami perubahan menjadi batu bata dan batako, menjadikan tampilan rumah ini menjadi lebih modern. Demikian juga dengan bahan penutup lantai yang dulunya terbuat dari tanah polpolan sudah banyak diganti dengan menggunakan lantai dari batu bata, semen dan keramik. Dengan perubahan bahan penutup lantai membuat ruangan menjadi lebih dingin dari sebelumnya dan juga beberapa fungsi yang dulunya dapat diwadahi dalam ruangan menjadi dipindah ke luar ruangan. Contohnya adalah memasak, dahulu air untuk membersihkan bahan makanan sebelum diolah dapat disiramkan langsung ke lantai tanah namun sekarang tidak bisa lagi. Sehingga fungsi memasak dipindah ke luar rumah dengan melakukan penambahan ruang.

4. Terjadi perubahan bentuk bangunan dengan pemotongan bagian bangunan dan kemudian disambungkan dengan bangunan lain yang lebih baru. Penghilangan sebagian bangunan berikut fungsi ruang yang di dalamnya menghasilkan suatu bentuk baru rumah yang baru, namun ciri utama masih dipertahankan yaitu Pedeman Gede dan Pelangkiran yang ada di dalam rumah. Sebuah karya arsitektur mengalami perubahan terkait dengan perkembangan arsitektur itu sendiri, hal ini tidak terlepas dari proses evolusi sosok arsitektur, sehingga dalam proses tersebut akan ada yang berubah dan akan ada yang tetap (Prijotomo, 1988). Perubahan tersebut dapat dilihat pada Gambar 6 dibawah. 


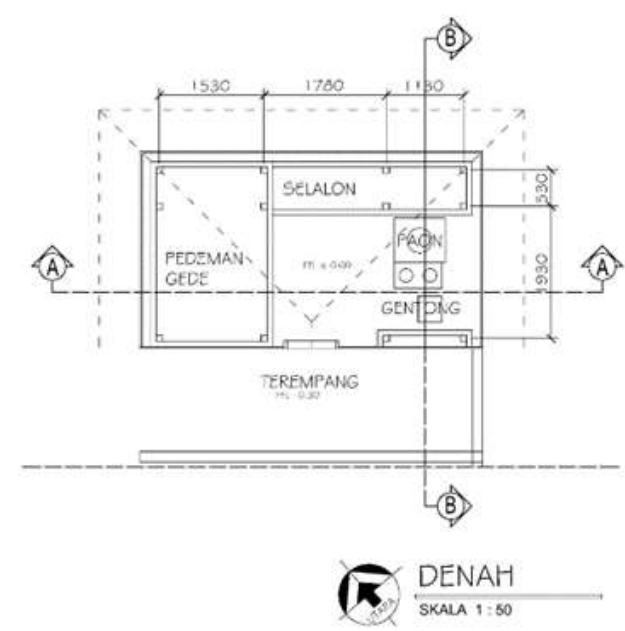

Gambar 6. Gambar pemotongan Pedeman Cenik Pada yang ada pada rumah tradisional (Sumber: hasil observasi penulis, 2016)

5. Fungsi keagamaan di dalam rumah yaitu Pelangkiran yang berada tepat diatas Pedeman Gede merupakan sebuah fungsi yang sakral dan tidak berubah (Gambar 7). Dari semua rumah yang diteliti, Pelangkiran masih utuh seperti sediakala walaupun rumah sudah mengalami transformasi ruang ataupun sudah tidak ditempati lagi. Fungsi Pedeman Gede dapat berubah namun Pelangkiran diatas Pedeman Gede tetap berbentuk dan berfungsi seperti dahulu. Demikian juga dengan Sanggah Kemulan Nganten yang ada di luar bangunan, tidak mengalami perubahan pada setiap rumah yang dikaji. Bahan dan posisi Sanggah Kemulan Nganten tetap pada posisi semula saat rumah tersebut dibangun. Biasanya apabila kepala keluarga sudah meninggal Sanggah Kemulan Nganten dapat ditiadakan, namun semua rumah yang dikaji tetap memiliki Sanggah ini walaupun beberapa rumah sudah tidak memiliki kepala keluarga lagi. Yang lebih menarik adalah penduduk yang sudah tidak lagi memiliki rumah tradisional dan memiliki rumah berarsitektur Bali modern tetap memiliki Sanggah Kemulan Nganten walaupun mereka juga memiliki Sanggah Kemulan Taksu seperti pada jaman Bali Majapahit. Ritual yang merupakan sebuat atribut budaya adalah merupakan faktor yang sangat penting dalam suatu tatanan masyarakat tertentu yang menghasilkan suatu setting, baik yang bersifat publik maupun privat dan menghasilkan sebuah struktur ruang tertentu (Knowles, 1996) Ruangan yang bersifat suci yang biasanya dipergunakan untuk kegiatan ritual bisanya menjadi suatu pusat orientasi dan identifikasi bagi manusia dan merupakan sebuah struktur ruang (Norberg-Schulz, 1979). Dapat dilihat bahwa fungsi ritual keagamaan yang diyakini oleh masyarakat Desa Pedawa merupakan suatu faktor penting dan identitas bagi masyarakat ini yang tidak bisa digantikan oleh fungsi ataupun obyek yang lain.
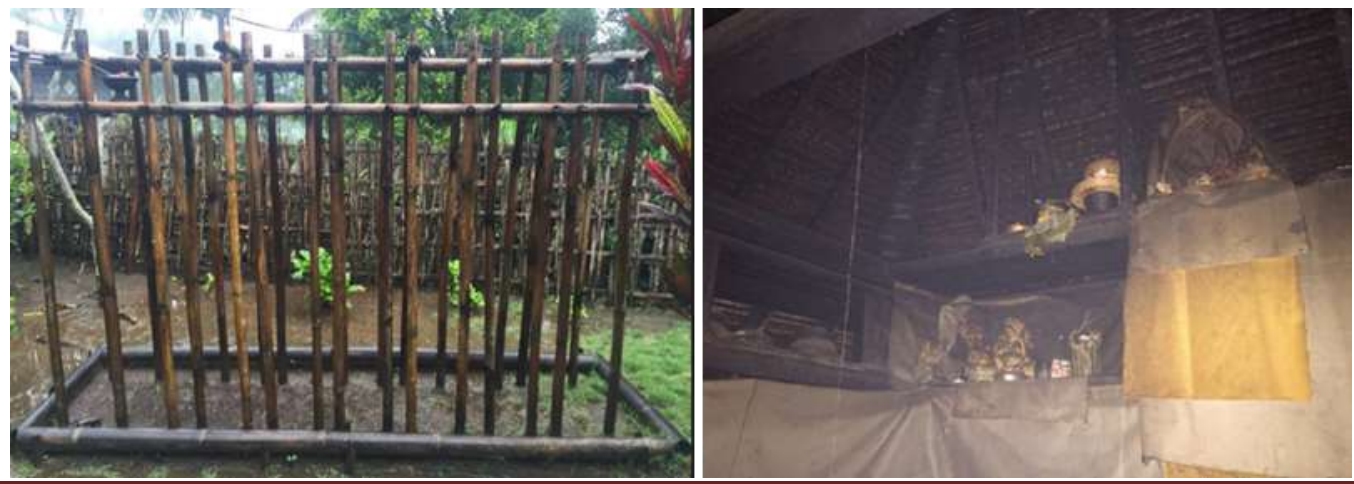
Gambar 7. Sanggah Kemulan Nganten - kiri, dan Pelangkiran- kanan

(Sumber: hasil observasi penulis)

\section{Simpulan}

Pembahasan menunjukkan bahwa terjadi perubahan secara fisik terhadap bentuk dan fungsi bangunan rumah tinggal tradisional di Desa Pedawa yang disebabkan oleh empat faktor penting yaitu; (1) Perubahan gaya hidup dan mata pencaharian masyarakat yang dulunya bertani menjadi memiliki mata pencaharian yang beragam dan beberapa diantaranya mulai meninggalkan pertanian; (2) Meningkatnya kebutuhan akan ruang baru, hal ini disebabkan karena pertambahan jumlah anggota keluarga dan juga gaya hidup serta mata pencaharian yang berbeda menuntut fungsi ruang yang berbeda. Dan pada dasarnya ruang adalah merupakan suatu pemahaman akan organisasi ruang yang sesuai dengan tujuan dari manusia sebagai penggunanya (Aspinall, 1993); (3) Ketahanan bahan bangunan terhadap cuaca, hal ini terjadi akibat bahan tradisional yang berkualitas sulit didapat sehingga masyarakat mengganti bahan tradisional dengan bahan yang lebih ekonomis dan mudah didapat serta tahan lama; dan (4) Minimnya pemahaman masyarakat tentang pentingnya konservasi bangunan tradisional, hal ini meyebabkan masyarakat kurang menghargai warisan budaya mereka khususnya bangunan rumah tinggal tradisional mereka, seiring dengan berkembangnya peradaban mereka yang menginginkan sesuatu yang baru dan lebih modern.

Dengan beragam perubahan yang terjadi, permasalahan muncul tanpa mereka sadari, yaitu mereka sedikit demi sedikit mulai menghilangkan karakter dan identitas yang merupakan warisan budaya leluhur mereka. Dengan bentuk, pola serta bahan yang sudah berbeda, keunikan rumah tinggal tradisional Desa Pedawa sudah mulai pudar. Sebagai contoh dapat dilihat dari penurunan tinggi atap akibat perubahan bahan dan struktur atap yang menjadi sama dengan rumah Bali masa kini, bahan dinding bangunan yang terbuat dari bata dan kaca membuat rumah ini tidak berbeda dengan rumah masa kini. Demikian juga dengan beberapa kondisi sebagai konsekuensi perubahan yang telah terjadi, beberapa aktifitas yang dahulu bisa dilakukan di dalam ruangan menjadi berubah dan berpindah tempat sesuai dengan perubahan wadah aktifitasnya. Perubahan bahan bangunan terutama lantai dan penambahan bukaan pada dinding telah membuat kondisi di dalam rumah menjadi tidak senyaman pada saat menggunakan bahan asli, seperti yang telah dijelaskan pada pembahasan diatas.

Namun dari semua perubahan yang terjadi, terdapat dua hal penting yang tidak berubah yaitu kepercayaan masyarakat Desa Pedawa yang kuat terhadap leluhur mereka Betara Betari dan Sang Pencipta yaitu Ida Sang Hyang Widhi Wasa. Derasnya perubahan terhadap bentuk dan fungsi ruang dan bangunan tidak mampu menggoyahkan kepercayaan mereka terhadap leluhur dan Sang Pencipta. Sanggah Kemulan Nganten dan Pelangkiran merupakan bagian yang paling utama dalam sebuah rumah tinggal tradisional di Desa Pedawa memberikan identitas yang kuat dan faktor penentu keberlangsungan rumah tradisional ini.

\section{Ucapan Terima Kasih}

Ucapan terimakasih kami sampaikan kepada Bapak Nyoman Sukarata Spd, selaku narasumber dan masyarakat Desa Pedawa yang telah dengan sukarela membantu peneliti selama observasi lapangan. Bapak I Made Yudi Jaya Ari Pucangan, ST atas segala dukungannya semenjak awal penelitian hingga akhir. Adik mahasiswa I Kadek Diantara 
dan Satria Ariwibawa yang sudah membantu melakukan dokumentasi dan pengukuran pada saat observasi lapangan dan penggambaran obyek studi.

\section{Daftar Pustaka}

(1979). Genius Loci. Electa/Rizolly, New York.

Appendix XVI.C: Peraturan Daerah Provinsi Bali Nomor 16 Tahun 2009 Tentang Rencana Tata Ruang Wilayah Provinsi Bali Tahun 2009-2029.

Aspinal, P. (1993). 'Aspect off Spatial Experience and Structure', in Farmer, B \& Louw, H, Companion to Contemporary Architectural Thought, Routledge, London.

Broadbent G, Bunt R \& C. Jencks. (1980). Signs, Symbols and Architecture. John Wiley \& Sons. Chichester.

Chetty, S .(1996). The Case Study Method for Research in Small-and Medium-Sized Firms. International Small Business Journal, vol. 15, no. 73, pp. 73-84.

Dinas Pekerjaan Umum Propinsi Bali. (1989) Inventarisasi Desa-Desa Tradisional Bali, Pemerintah Propinsi Daerah Tingkat I Bali, Dinas Pekerjaan Umum Propinsi Bali, Proyek Perencanaan Konservasi Lingkungan Desa (1988/1989).

Eisenhardt, KM. (1989). Building theories from Case Study Research, Academy of Management Review, vol. 14, no. 4, pp. 532-550.

Inventarisasi Desa-Desa Tradisional Bali. (1989). Pemerintah Propinsi Daerah Tingkat I Bali, Dinas Pekerjaan Umum Propinsi Bali, Proyek Perencanaan Konservasi Lingkungan Desa (1988/1989)

Knowles, R. (1996). Rhythm and Ritual, Maintaining the Identity of a Place, Journal Traditional Dwelling and Settlements, Vol. 94, p: 94-96, Berkeley, IASTE (1996), University of California.

M.McCutcheon, D \& Meredith, JR. (1993). Conducting case study research in operation management, Journal of Operations Management, vol. 11, pp. 239-256.

Muller, C. (2011). Bali Aga Villages; field work in the 1980s, Walsh Bay Press.

Norberg-Schulz, C (19.7). Intentions in Architecture. The M.LT Press, Cambridge Massachusetts.

Parimin, A, P. (1986). Fundamental Study on Spatial Formation of Island Village: Environmental Hierarchy of Sacred-Profane Concept In Bali. Disertasi, Universitas Osaka, Japan.

Prijotomo, J. (1988). Pasang Surut Arsitektur di Indonesia. CV. Ardjun. Jakarta,

- Pustaka dari jurnal:

Stake, R. E. (1978). The Case Study method in Social Inquiry. American Educational Research Association, vol. 7, no. 2, pp. 5-8.

Sulistyawati. (1985). Preservasi Lingkungan Perumahan Pedesaan dan Rumah Tradisional Bali di Desa Bantas, Kabupaten Tabanan', P3M, Universitas Udayana, Denpasar.

Yin, R. K. (2009). Case Study Research : Design and Methods. Fourth Edition edn, SAGE, Los Angeles.

Yudantini, NM, \& Kadek Wisnawa. (2013). Rumah Tinggal Bali Aga; Arsitektur Minimalis dan Fungsionalis, Semnas Reinterpretasi Identitas Arsitektur Nusantara, Bali-2013, ISBN No. 978-602-7776-68-5 